\title{
Analyzing tree cores to detect petroleum hydrocarbon-contaminated groundwater at a former landfill site in the community of Happy Valley-Goose Bay, eastern Canadian subarctic
}

\author{
Fonkwe, Merline L D; Trapp, Stefan
}

Published in:

Environmental Science and Pollution Research

Link to article, DOI:

10.1007/s11356-016-6802-2

Publication date:

2016

Document Version

Peer reviewed version

Link back to DTU Orbit

\section{Citation $(A P A)$ :}

Fonkwe, M. L. D., \& Trapp, S. (2016). Analyzing tree cores to detect petroleum hydrocarbon-contaminated groundwater at a former landfill site in the community of Happy Valley-Goose Bay, eastern Canadian subarctic. Environmental Science and Pollution Research, 23(16), 16137-16151. https://doi.org/10.1007/s11356-016-68022

\section{General rights}

Copyright and moral rights for the publications made accessible in the public portal are retained by the authors and/or other copyright owners and it is a condition of accessing publications that users recognise and abide by the legal requirements associated with these rights.

- Users may download and print one copy of any publication from the public portal for the purpose of private study or research.

- You may not further distribute the material or use it for any profit-making activity or commercial gain

- You may freely distribute the URL identifying the publication in the public portal 
DOI 10.1007/s11356-016-6802-2

Analyzing tree cores to detect petroleum hydrocarbon-contaminated groundwater at a former landfill site in the community of Happy Valley-Goose Bay, eastern Canadian subarctic

${ }^{b}$ Department of Environmental Engineering, Technical University of Denmark, 2800 Kgs. Lyngby, Denmark 


\section{Abstract}

17 This research examines the feasibility of analyzing tree cores to detect BTEX compounds and

18 MTBE in groundwater in eastern Canada subarctic environments, using a former landfill site in the

19 remote community of Happy Valley-Goose Bay, Labrador. Petroleum hydrocarbon contamination at

20 the landfill site is the result of environmentally unsound pre-1990's disposal of households and

21 industrial solid wastes. Tree cores were taken from trembling aspen, black spruce and white birch

22 and analyzed by headspace-gas chromatography-mass spectrometry. BTEX compounds were

23 detected in tree cores, corroborating known groundwater contamination. A zone of anomalously

24 high concentrations of total BTEX constituents was identified and recommended for monitoring by

25 groundwater wells. Tree cores collected outside the landfill site at a local control area suggest the

26 migration of contaminants off-site. Tree species exhibit different concentrations of BTEX

27 constituents, indicating selective uptake and accumulation. Meanwhile, MTBE was not found in the

28 tree cores and is considered to be absent in the groundwater. The results demonstrate that tree-core

29 analysis can be useful for detecting anomalous concentrations of petroleum hydrocarbons, such as

30 BTEX compounds, in subarctic sites with shallow unconfined aquifers and permeable soils. This

31 method can therefore aid in the proper management of contamination during landfill operations and

32 after site closures.

33 Keywords: Labrador; solid waste disposal; organic pollutants; phytoscreening; BTEX compounds;

34 MTBE; preliminary site assessments; remote location 


\section{Introduction}

37 Landfilling remains the most prevalent method of organized solid waste disposal in remote

38 communities of the eastern Canadian subarctic (Ryan 2010; Zagozewski et al. 2011). There has been

39 and continues to be substantial environmental controversy surrounding landfilling practices (El-

$40 \quad$ Fadel et al. 1997; Rowe et al. 1997), though solid waste disposal facilities have evolved from

41 uncovered and unlined landfills or open dumps to modern engineered landfills (e.g. Barrett and

42 Lawler 1995; Slack et al. 2005; Eggen et al. 2010). However, subsurface pollution may occur at any

43 time during landfills' active and post-closure phases (Allen 2001; Sawhey and Kozloski 2004).

44 This represents a human health and environmental hazard, which requires control measures by solid

45 waste management and pollution control authorities (Christensen et al. 2001; Fatta et al. 1999;

46 Kjeldsen et al. 2002; Manfredi et al. 2009). In order to better evaluate the pollution risks posed by

47 leachate emissions from landfills into the underlying soil and groundwater, and to inform corrective

48 or remedial actions, such sites must be characterized and monitored long-term (Cifrian et al. 2013;

49 El-Fadel et al. 2001; Laner et al. 2011). The traditional technique of sampling (soil via boreholes

50 and groundwater via monitoring wells) is extremely costly, technically difficult, and time-

51 consuming to implement, particularly at remote subarctic sites. Therefore, attention is increasingly

52 being given to tree-core analysis, as a simple and cost-effective field-screening approach that can

53 successfully identify and vector borehole and well drilling towards possible zones of subsurface

54 contamination (Algreen et al. 2015; Burken et al. 2011; Vroblesky et al. 1999).

55 Tree-core analysis (also referred as to phytoscreening) has been used in environmental science

56 to detect and monitor subsurface contamination by a variety of volatile organic compounds (VOCs)

57 since the pioneering research by Vroblesky et al. (1999). Trees take up compounds through their

58 roots, bark, or leaves and can incorporate the compounds into their cells; therefore, the chemistry of

59 soil, groundwater and atmosphere can be inferred via the analysis of tree tissues (Cutter and Guyette 
1993; Padilla and Anderson 2002). To date, compared to the attention paid to chlorinated ethenes,

61 few studies have analyzed tree cores to assess soil and groundwater contamination by petroleum

62 hydrocarbon constituents, like benzene, toluene, ethylbenzene and m, p, o-xylenes (collectively

63 referred to as BTEX) or methyl tertiary-butyl ether (MTBE) or both (Algreen 2015; Algreen et al.

64 2015; Holm 2011; Landmeyer et al. 2000; Rein and Trapp 2009; Sorek et al. 2008; Trapp et al.

65 2005; Weishaar et al. 2009). The studies undertaken were all located in temperate, subtropical, or

66 mediterranean regions, and they have met with some success in providing the semi-quantitative data

67 needed for preliminary site evaluations, especially for BTEX compounds. Besides the practical and

68 financial convenience, another crucial advantage of tree-core analysis is that because of its root

69 system, a single tree can take up compounds from a much larger area (many cubic meters of soil and

70 groundwater) than a single traditional soil or groundwater sample (Dunn 2007). Nonetheless, the

71 applicability of tree-core analysis must be evaluated site by site, because compound uptakes by trees

72 depend on site-specific conditions, the physiological characteristics of the tree species used, and the

73 properties of the contaminants in question (Cutter and Guyette 1993; Trapp 2007).

74 The feasibility of using tree-core analysis to detect subsurface contamination by VOCs has not

75 been studied in the eastern Canadian subarctic. This study therefore aimed to determine whether the

76 analysis of tree cores could be useful in this context, using the most common deciduous and

77 coniferous tree species to assess concentrations of subsurface BTEX compounds and MTBE at a

78 former landfill site in the remote, subarctic community of Happy Valley-Goose Bay in Labrador. If

79 substantiated as a valuable approach, tree-core analysis could be integrated into preliminary site

80 evaluations of possible subsurface contamination at other old or still operational landfills and other

81 facilities in efforts to minimize negative impacts on the environment and public health. In addition,

82 this paper compiles and describes the data available in open literature to provide, in conjunction

83 with the present study, a foundation for the application of tree-core analysis to track subsurface

84 pollution by petroleum hydrocarbons. 


\section{Materials and methods}

\subsection{Description of the study area}

Happy Valley-Goose Bay is a small, remote community in the province of Newfoundland and Labrador in Canada, at the western extremity of Lake Melville, an inlet of the Labrador Sea (53 $30^{\prime}$ $\mathrm{N}$ and $60^{\circ} 41^{\prime} \mathrm{W}$; Fig. 1). It covers an area of $306 \mathrm{~km} 2$ and has a population of 7552 (Government of Canada's 2011 census). The climate is subarctic, marked by heavy snowfall from November to March with snow covering the ground from November to May and high rainfall from June to September (average annual precipitation of $762 \mathrm{~mm}$ ). The average daily temperatures remain below freezing from November to April and vary between $-17.6^{\circ} \mathrm{C}$ and $15.5^{\circ} \mathrm{C}$ (https://weather.gc.ca/canada_e.html). Surficial geology is composed of Quaternary marine and fluvial sediments to a depth of about $100 \mathrm{~m}$, consisting dominantly of fine- to medium-grained sands and interbedded marine silts and clay, overlying a conglomerate and sandstone sequence (Liverman 1997; Nunn and van Nosttrand 1996; Wardle and Ash 1986). Bedrock is composed of a Paleoproterozoic anorthosite-mangerite-charnockite-granite suite and the massif anorthosite of the Cape Caribou River Allochthon (Valvasori et al. 2015; Wardle and Ash 1986).

The community of Happy Valley-Goose Bay is home of the Canadian Force Base (CFB) 5 Wing Goose Bay. This military air force base was constructed in 1941 on a flat-lying terrace, which has an elevation between 40 to $50 \mathrm{~m}$ (a.s.1.) and is bordered by the Terrington Basin to the north and the Churchill River to the south (Fig. 1). It played an important role as a refuelling base to facilitate transatlantic flights during World War II and afterwards supported low-level flight training, airdefence exercises and bombing practices for the North Atlantic Treaty Organization (Wells 2013). CFB 5 Wing Goose Bay remained a strategic military air base until 1987 and still continues today to support allied low-level flight training and multinational flying operations. Before 1990, a variety of residential and industrial wastes generated at CFB 5 Wing Goose Bay were disposed of on-site at 
109 several dumping areas making up a poorly-regulated and unlined landfill along the escarpment at the

110 south-southeast boundary of the military property (AMEC 2009; JWEL 1992; Fig.1).

111 2.2. Landfill site: physiography and hydrogeology

112 The landfill site covers approximately $6 \mathrm{~km} 2$ of low-lying land at an average elevation of $10 \mathrm{~m}$

113 (a.s.l.). It has received mainly drums/containers of motor oil, petroleum hydrocarbons, such as

114 gasoline, jet and diesel fuels, lubricants and pesticides, and also construction and demolition debris

115 and household wastes from approximately 1941 to 1990 (Figs. 1 and 2; JWEL 1992; BFA 1996).

116 The refuse was covered at different points of time with sand (JWEL 1992); however, surface

117 metallic debris is still visible (Fig. 3). The vegetation is dominated by grasses and locally forested

118 areas, which consist of a mixture of coniferous and deciduous trees. Depth to groundwater averages

$1192.5 \mathrm{~m}$ and in several locations, groundwater intercepts the land surface and forms wetlands (swamps

120 and marshes) with a number of elongated surface water bodies, collectively named stillwater

121 (AMEC 2009; Fig. 2). Groundwater is unconfined and flows south to southeast towards the

122 Churchill River, following low topography (see Fig. 2). The hydraulic conductivity of saturated

123 subsurface layers at the landfill site ranges from $3.6 \mathrm{x} \cdot 10-5 \mathrm{~m} / \mathrm{s}$ to $1.0 \mathrm{x} \cdot 10-2 \mathrm{~m} / \mathrm{s}$ (AMEC 2009;

124 2011). Horizontal hydraulic gradients across the Landfill site averaged to $0.001 \mathrm{~m} / \mathrm{m}$. Vertical

125 hydraulic gradients at the well nest locations ranged from $0.009 \mathrm{~m} / \mathrm{m}$ to $0.136 \mathrm{~m} / \mathrm{m}$ (AMEC, 2009).

126 Assessments of the landfill site since 1991 have revealed that it is contaminated by petroleum

127 products, polycyclic aromatic hydrocarbons (PAHs), polychlorinated biphenyls (PCBs), pesticides,

128 and heavy metals (AMEC 2011:2009; BFA 1996; JWEL 1992). Clean-up activities have been

129 undertaken since 1993 with the removal of several thousands of drums/containers, many still with

130 residual contents; however, an unknown number of drums remains buried at the site (AMEC 2009;

131 BFA 1996; Curtis and Lammey 1998; Wells 2013). Total BTEX concentrations up to $2744 \mathrm{mg} / \mathrm{L}$

132 have been obtained from discarded fuel drums (JWEL 1992). Nests of groundwater monitoring 
133 wells have been installed at selected parts of the landfill site. Two separate plumes of BTEX

134 compounds have been identified cross-cutting stillwater \#4 (AMEC 2009; FEI 2006; Fig. 2). There,

135 measured groundwater samples have indicated concentration ranges of $2.0-990.0 \mu \mathrm{g} / \mathrm{L}$ for

136 benzene, $6.5-27.9 \mu \mathrm{g} / \mathrm{L}$ for toluene, $0.7-27.9 \mu \mathrm{g} / \mathrm{L}$ for ethylbenzene and $2.0-17.1 \mu \mathrm{g} / \mathrm{L}$ for total

137 xylenes; MTBE was not detected (AMEC 2011: 2009; FEI 2006).

$138 \quad$ 2.3. Field sampling

139 Tree-core samples were taken in the eastern portion of the landfill site (Fig. 2). This area is of

140 concern because initial site investigations found VOCs (including BTEX compounds), PAHs, heavy

141 metals, and pesticides in both groundwater (from test pits; locations not shown) and surface water

142 (including samples from the stillwaters); VOCs and PAHs in groundwater exceeded the applicable

143 Groundwater Quality Standards (AMEC 2009: 2011; FEI 2006). Therefore, continued monitoring is

144 necessary for risk management and/or mitigation. This area is easy to access and has experienced

145 only minimally invasive remediation activities, which have preserved mature trees, suitable for use

146 in tree-core analysis approach (Cutter and Guyette 1993).

147 The site-specific background conditions (i.e. diffuse anthropogenic influences) of the

148 subsurface environment are unknown, as are those of the study area in general. Moreover, it was

149 impossible to confidently assign a typical background location within the study area where the

150 physical and environmental characteristics were representative of the site overall. Nonetheless, a

151 local control site located outside of the landfill site at about $2 \mathrm{~km}$ downstream towards the south-

152 southeast was selected for the collection of additional tree-core samples (Fig.1), to assess the

153 possibility of the landfill site contributing to off-site contaminant levels nearby.

\section{2.4. Tree-core collection and handling}

155 Tree-core samples were collected on three days, between 18 August 2014 and 2 September

156 2014, according to the criteria and established procedures by Cutter and Guyette (1993), Holm et al. 
157 (2011) and Vroblesky (2008). During sampling, the weather was dry with low wind (6 - $22 \mathrm{~km} / \mathrm{h})$

158 and daily temperatures ranged between $14^{\circ} \mathrm{C}$ and $24^{\circ} \mathrm{C}$. Mature (stem diameter between 18 and 39

$159 \mathrm{~cm}$ ) and visibly healthy trees were sampled randomly at the landfill site, including 20 trembling

160 aspens (Populus tremuloides), 15 black spruces (Picea mariana) and 9 white birches (Betula

161 papyrifera) (Fig. 2). In addition, tree-core samples were taken from 3 trembling aspens and 4 black

162 spruces at the local control site. Core samples were extracted from the north or northwest side of

163 each tree (the side facing the direction of groundwater flow), using a $35.5 \mathrm{~cm}$ long, $5.15 \mathrm{~mm}$

164 diameter increment tree-corer (Haglöf®). Tree cores $8 \mathrm{~cm}$ in length were taken at a height of about 1

$165 \mathrm{~m}$ above the ground surface, the bark was discarded and the wood quickly broken into several

166 smaller pieces, then placed into $20 \mathrm{~mL}$ glass screw-top vials sealed with PTFE-lined septum caps

167 (Gerstel@). The vials were immediately stored in an iced cooler container in the field and transferred

168 into a $4^{\circ} \mathrm{C}$ refrigerator at the end of each day for overnight storage. The following day, the core

169 samples were freighted by air in an iced cooler box at Memorial University of Newfoundland in St.

170 John's (Fig. 1) for analysis. Further details are given in the Supplementary Material.

\section{2.5. Tree-core analysis}

172 Concentrations of BTEX compounds and MTBE in tree-core samples were determined by

173 headspace-gas chromatography-mass spectrometry (HS-GC-MS) using an Agilent 6890N gas

174 chromatograph equipped with a 5975C mass selective detector and a DB-624 capillary column (see

175 Supplementary Material). Upon receipt in the laboratory the same or next shipping day, the core

176 samples were either prepared for immediate analysis or stored at $4^{\circ} \mathrm{C}$ until analysis within 3 to 5

177 days of sampling. Before analysis, core samples were allowed to equilibrate in the vials for 24 hours

178 at room temperature $\left(21^{\circ} \mathrm{C}\right)$. To generate calibration curves, standard solutions were prepared in

179 concentration ranges of $0.4-10 \mu \mathrm{g} / \mathrm{L}$ for MTBE and all the BTEX constituents, along with $10-400$

$180 \mu \mathrm{g} / \mathrm{L}$ for toluene from a certified reference material (CRM47505 Supelco®) diluted in deionized 
water (see Supplementary Material). The vials were heated at $70^{\circ} \mathrm{C}$ in an incubator for 30 minutes

182 under gentle shaking and $200 \mu \mathrm{L}$ volume of headspace was extracted from each vial using a heated

183 gas-tight syringe and immediately injected into the GC instrument for analysis. The m-and p-

184 xylenes could not be resolved and were measured together. The calibration curves (peak areas of

185 quantification ions vs. concentration of standards in aqueous phase) were linear $\left(\mathrm{R}^{2}>0.996\right)$.

186 Results for the core samples containing the compounds of interest at a concentration below $0.4 \mu \mathrm{g} / \mathrm{L}$

187 (lower end of the calibration interval) were reported as such $(<0.4 \mu \mathrm{g} / \mathrm{L})$ if the signal to noise ratio

188 was higher than 3; in this case $0.4 \mu \mathrm{g} / \mathrm{L}$ represents the quantification limit (QL). If the signal to

189 noise ratio was lower than 3 , the results were reported as below the detection limit $(<\mathrm{DL})$. The

190 recovery efficiency of MTBE and BTEX compounds was tested by spiking four core samples from

191 white birch trees with $1 \mathrm{~mL}$ of the prepared standard solution at a concentration of $4.0 \mu \mathrm{g} / \mathrm{L}$.

192 Recoveries ranged from $29 \%$ to $77 \%$ and were related to the octanol-water partition coefficients of

193 the compounds (see Supplementary Material for details). No correction for recovery was performed

194 since semi-quantitative data from tree-core analyses are in themselves sufficient for field screening

195 of groundwater contamination by VOCs (e.g. Algreen et al. 2015; Vrobesky 2008). Contaminant

196 concentrations in core samples are reported in units of micrograms per liter of headspace. $10 \mathrm{ug} / \mathrm{L}$

197 corresponds to about $0.288 \mathrm{mg} / \mathrm{kg}$ in dry wood. Any resulting values below the QL were assigned to

198 half QL for representation purpose (see Table 1, 2 and 3).

\subsection{Data quality assessment}

The quality of sampling, sample handling and analytical data was monitored by collecting travel

201 blanks, field trip blanks, air blanks and field duplicates (details in Supplementary Material). Trace

202 amounts (almost all values < QL) of toluene, ethylbenzene and xylenes were detected in travel

203 blanks; BTEX components were also detected in field trip blanks with values also lower than the

204 laboratory QL. This suggests that the core samples may have been contaminated by the Styrofoam 
containers used for shipping the core samples (details in Supplementary Material). However, this

206 was found to have no significant effect on the analytical results of the tree-core samples and

207 therefore, blanks corrections were not applied. Air samples at the vicinity of the trees contained

208 trace amounts (all values $<$ QL) of BTEX components with limited presence of benzene. Obtained

209 results for field duplicate pairs, collected approximately $1 \mathrm{~cm}$ vertically apart at selected trees, show

210 good repeatability with relative standard deviation (RSD) up to $5 \%$ for 5 of the 6 field duplicate

211 pairs (see Table 1 and 2).

\section{3. Results and Discussion}

\subsection{Concentrations of the BTEX compounds in tree cores}

BTEX compounds were identified, in general, in tree-core samples at both the landfill site and

215 the local control site. At the landfill site (Table 1), benzene concentrations were generally low $(0.20$

$216 \mu \mathrm{g} / \mathrm{L}$ ) with only two core samples having higher values, of $1.1 \mu \mathrm{g} / \mathrm{L}$ and $2.3 \mu \mathrm{g} / \mathrm{L}$ respectively. In

217 contrast, toluene content is much higher with the concentrations in the majority of the samples (40)

218 in the range $0.40 \mu \mathrm{g} / \mathrm{L}$ to $137 \mu \mathrm{g} / \mathrm{L}$; the remaining samples (16) have a toluene concentration of 0.20

$219 \mu \mathrm{g} / \mathrm{L}$. Ethylbenzene was identified in small amounts with the majority of the core samples having a

220 concentration of $0.2 \mu \mathrm{g} / \mathrm{L}$; only one sample yielded a concentration of $0.93 \mu \mathrm{g} / \mathrm{L}$. When detected,

221 the content of $\mathrm{m}$ - and p-xylene was $0.40 \mu \mathrm{g} / \mathrm{L}$ in most of the samples (31), with only one sample

222 having a concentration of $1.13 \mu \mathrm{g} / \mathrm{L}$. In comparison with other BTEX constituents, the occurrence of

$223 \mathrm{o}-\mathrm{xylene}$ was less frequent and restricted to fewer samples (10) at a concentration of $0.20 \mu \mathrm{g} / \mathrm{L}$.

224 At the local control site (Table 2), on the other hand, the concentrations were low but similar to

225 those obtained at the landfill site for benzene $(0.20 \mu \mathrm{g} / \mathrm{L})$ and ethylbenzene $(0.20 \mu \mathrm{g} / \mathrm{L})$, and for $\mathrm{m}$ -

226 and p-xylene $(0.40 \mu \mathrm{g} / \mathrm{L})$, which were detected only in some core samples. As for toluene, it was

227 found at the highest concentration when compared with the other BTEX constituents. Toluene 
content in most of the samples ranged between $1.1 \mu \mathrm{g} / \mathrm{L}$ to $40.2 \mu \mathrm{g} / \mathrm{L}$, whereas low toluene

229 concentrations of $0.20 \mu \mathrm{g} / \mathrm{L}$ were also measured in aspen core samples.

230 At the landfill site, all tree species contained detectable concentrations of all or selected BTEX

231 compounds in varied proportions. This is supported by the measurement tests of groundwater and

232 surface water in the sampling area (Serco 2001; AMEC 2011). In October 2000, elevated BTEX

233 with maximum concentration of $1180 \mu \mathrm{g} / \mathrm{L}$ for benzene and $13 \mu \mathrm{g} / \mathrm{L}$ for Ethylbenzene, was

234 observed in the groundwater from test pits (locations not shown) at the head of stillwater \#1,

235 encompassing trees nos. 3, 5, 13, 4, 30 and 31 (Serco 2001; see Figs. 2 and 4). Further sampling

236 program in February 2010, indicated BTEX contamination in groundwater samples in the area

237 around stillwater \#2, enclosing trees nos. 15, 8, 1,9 and 7; measured groundwater samples indicated

238 concentration ranges of $0.5-14.0 \mu \mathrm{g} / \mathrm{L}$ for benzene, $0.3-31.0 \mu \mathrm{g} / \mathrm{L}$ for toluene, $0.6-5.4 \mu \mathrm{g} / \mathrm{L}$ for

239 ethylbenzene and $0.26-37.0 \mu \mathrm{g} / \mathrm{L}$ for total xylenes (AMEC 2011). Moreover, although low, the

240 concentrations of BTEX in tree-core samples were corroborate groundwater results in the vicinity of

241 the sampling area (Fig. 2: AMEC 2011: 2009). This is expected because plants such as trees are

242 passive samplers of subsurface contaminants and they have the ability to sample a much larger area

243 than that afforded by groundwater samples (Dunn 2007). This suggests that groundwater BTEX

244 concentration is the primary factor governing the concentrations obtained from tree-core samples at

245 this site. As for the local control area, the BTEX compounds in tree-core samples indicate the

246 possible migration of contaminants from the landfill site. Probable contaminant migration off-site

247 has previously been mentioned by the appropriate authorities (in newspaper archives), who have

248 urge the abandonment of agricultural lands adjacent to the local control area.

249 These findings demonstrate that tree-core analysis can indeed be used to detect BTEX

250 contaminated shallow groundwater ( 2.5 m deep) in subarctic environments, much as in

251 mediterranean and temperate environments, as shown by Algreen et al. (2015) and Sorek et al. 
252 (2008), who used core samples from eucalyptus (Eucalyptus camaldulensis) and rosewood

253 (Dalbergia sisso), and willow (Salix sp.) and aspen (Populus tremula), respectively. The low content

254 of BTEX in the tree cores might be due to BTEX degradation (Sorek et al. 2008). Studies on

255 phytoremediation of petroleum products confirm a relatively rapid break-down of petroleum

256 hydrocarbons, including BTEX, in the root zones of tree stands and soil profiles under natural

257 aerobic conditions (Nichols et al. 2014; Wilson et al. 2013).

\subsection{Spatial distribution of the sum BTEX in tree cores}

259 The normal quantile - quantile $(\mathrm{Q}-\mathrm{Q})$ plot was used to identify the background threshold

260 value (and anomalous values) of the sum BTEX concentrations in tree-core samples (e.g. Reimann

261 et al. 2005; Papastergios et al. 2011). Two different populations were identified using changes

262 (breaks) in the slope of a probability plot of sum BTEX concentrations, interpreted as indicating

263 background (lower) and anomalous (higher) values (Fig. 3). The first bend of the slope on the Q-Q

264 plot curve occurs at sum BTEX concentrations of $1.7 \mu \mathrm{g} / \mathrm{L}$; values less than $1.7 \mu \mathrm{g} / \mathrm{L}$ represent

265 background values, while values above $1.7 \mu \mathrm{g} / \mathrm{L}$ are anomalous. The anomalous values are mostly

266 dominated by high levels of toluene, with two values dominated by benzene (Fig. 3). To delineate

267 anomalous zones, core samples from each tree species representing the two populations are shown

268 with different symbols and colors on a separate sample collection map (Fig. 4). The clustering of

269 anomalous values of sum BTEX compounds in tree-core samples is observed between stillwater \#2

270 and \#3 and at the vicinity of stillwater \#4. These delineated zones of elevated sum BTEX

271 concentrations are optimal for the installation of groundwater monitoring wells for further

272 investigations of the site.

\section{$273 \quad 3.3$ Comparison of BTEX compounds uptake between tree species}

274 From Table 1 it can be seen that toluene concentrations are clearly higher in black spruce (mean

$27542.5 \mu \mathrm{g} / \mathrm{L}$ ) than in aspen (mean $0.91 \mu \mathrm{g} / \mathrm{L}$ ) or birch (mean $0.8 \mu \mathrm{g} / \mathrm{L})$. Pine trees have been observed 
to emit elevated levels of toluene under stress (Heiden et al. 1999) and contribute to atmospheric

277 levels of toluene (White at al. 2009), so an endogenous, natural source in black spruce cannot be

278 excluded beforehand. However, some arguments support the possibility that measured

279 concentrations more likely originate from external sources, i.e. groundwater. First, the wide range of

280 values (5.4 to $146 \mu \mathrm{g} / \mathrm{L})$ does not indicate production of toluene by black spruce. Second, more

281 importantly, the highest concentrations of toluene in black spruce (sample 26) are closely

282 neighbored by the highest concentrations of toluene in aspen (sample 27) (Fig. 4). Moreover, the

283 next samples in this direction (nos. 28 and 29) have the highest levels of benzene measured in aspen

284 wood (Fig. 4). Thus, contamination is the most likely explanation for the elevated levels found in the

285 trees. Although tree uptake of VOCs depends on species-specific physiology, toluene is most likely

286 to be absorbed and accumulated in larger amounts than other BTEX constituents, or perhaps more

287 stable, as observed in this study and in previous research (Algreen 2015; Algreen et al. 2015; Sorek

288 et al. 2008); this finding is independent of climatic environments and other specific site conditions.

\subsection{Concentrations of MTBE in tree cores}

290 None of the tree-core samples collected at the landfill site or local control area contained a

291 detectable concentration of MTBE. At the landfill site, MTBE results corroborate with available

292 groundwater data within or at the vicinity of the sampling area (AMEC 2012: 2011: 2009; Fig. 2).

293 Although MTBE was not found in monitoring wells, assessment of subsurface MTBE contamination

294 in this work was prompted by the fact that MTBE and the BTEX compounds are commonly

295 associated with petroleum hydrocarbon-contaminated groundwater, and by evidence that tree-core

296 analysis is sometimes able to identify subsurface contamination undetected by traditional

297 groundwater monitoring (e.g. Larsen et al. 2008). When compared with BTEX compounds, MTBE

298 is more resistant to biodegradation, has a lower log Kow, a greater tendency to move rapidly

299 through soil and groundwater, and is readily available for tree uptake and translocation (Briggs et al. 
301 demonstrated in both laboratory and field conditions, using trees from different species.

302 Experiments conducted by Burken and Schnoor (1998) and Ma et al. (2004), have indicated uptake

303 of MTBE by poplar (Populus spp.) and eucalyptus (Eucalyptus spp.) trees. These laboratory findings

304 were later corroborated by the identification of MTBE in mature oak trees (Quercus virginiana)

305 growing above gasoline-contaminated groundwater $<3.9 \mathrm{~m}$ bgs (Landmeyer et al. 2000).

306 Conversely, a more recent investigation has found no MTBE in tree-cores from mature (stem

307 diameter $>10 \mathrm{~cm}$ ) willow and aspen trees at a site with known jet fuel-contaminated subsoil and

308 shallow (2-3 m deep) groundwater (Algreen et al. 2015). Therefore, the absence of MTBE in core

309 samples is an indication of the absence of groundwater MTBE contamination at this site. Given that

310 buried drums are still buried at the landfill site and may leak their contents at any time, constituting

311 a possible source of MTBE in subsurface soil and groundwater, continuous monitoring remain

312 necessary until cleanup is complete at the landfill site.

3134 Compilation and description of available data from open literature: The flops and tops

314 in BTEX compounds detection using tree-core analysis

315 Among the studies using tree-core analysis to detect subsurface contamination by VOCs, many

316 have successfully investigated chlorinated ethenes, such as tetrachloroethylene (PCE) and

317 trichloroethylene (TCE) (e.g. Vroblesky et al. 2004, 1999; Larsen et al. 2008; Limmer et al. 2011;

318 Limmer and Burken 2015).Schumacher et al., 2004; Sorek et al. 2008; Wittlingerova et al. 2013). In

319 contrast, reports of successful applications for tracking soil and groundwater contamination by

320 petroleum hydrocarbons, including BTEX compounds, are rare, even though BTEX compounds are

321 also frequent subsurface pollutants and are similarly soluble in water. It may be that tree-core

322 analyses for assessing BTEX compounds have encountered some limitations, which in some cases,

323 lead to less successful applications, most of which remain unpublished. The studies described in this 
324 section are summarized together with the present study for comparison in Table 3 . The data are from

325 a number of contaminated sites in a range of ecosystems with tree-core samples from 15 different

326 tree species and measurement of BTEX compounds performed mostly by headspace extraction, or in

327 one case study, by headspace solid-phase microextraction followed by gas chromatography-mass

328 spectrometry.

329 Rein and Trapp (2009) carried out tree-core analysis at a former hydrogenation plant near Zeitz

330 (Germany), in an area of known very high benzene groundwater contamination (100 to > 1000

$331 \mathrm{mg} / \mathrm{L}$ ). In May 2009, 14 tree-core samples were taken across the plume. Toluene could not be

332 detected in any of the tree cores, and benzene was only found in one tree in the source zone at a

333 rather low concentration of $6.4 \mu \mathrm{g} / \mathrm{kg}$ wood dry weight $(\mathrm{dw})$. Sixteen additional core samples were

334 taken in July 2009 and no BTEX compounds were detected, except in two trees from the benzene

335 source zone, with benzene concentrations of 5.5 and $4.2 \mu \mathrm{g} / \mathrm{kg}$ wood $\mathrm{dw}$.

336 At the Hradčany site, a former Soviet military airport in the Czech Republic, a free-phase layer

337 of jet fuel covered the groundwater at $8 \mathrm{~m}$ below ground surface (bgs). Levels of petroleum

338 hydrocarbons in soil ranged from 10 to $18000 \mathrm{mg} / \mathrm{kg}$ soil dw (Machackova et al. 2008). About 20

339 tree-core samples were collected and BTEX compounds were detected only in those trees growing

340 on the gas plume of the ventilation outlets of the soil venting system (Trapp et al. 2005).

341 At the former gas works site in Søllerød (Denmark), BTEX compounds are still present in

342 groundwater at 4 to $5 \mathrm{~m}$ bgs $(25$ to $23000 \mu \mathrm{g} / \mathrm{L}$; benzene $<0.2$ to $950 \mu \mathrm{g} / \mathrm{L}$ ) and in soil (sum BTEX

$343100 \mathrm{mg} / \mathrm{kg}, 1$ sample). The corresponding levels in tree-core samples obtained by Algreen (2015)

344 were maximum $0.1 \mu \mathrm{g} / \mathrm{kg}$ benzene and $0.05 \mu \mathrm{g} / \mathrm{kg}$ xylene (recalculated from $\mu \mathrm{g} / \mathrm{L}$ for a wood

345 density of $1 \mathrm{~kg} / \mathrm{L}$ ), and detects were limited to three samples (benzene) and one sample (xylene)

346 respectively, out of 52. Toluene and ethylbenzene were not detected in any sample. Moreover, the

347 anomalous tree-core samples were not near the location of highest groundwater concentrations. At

348 another Danish site near Gentofte, concentrations of benzene in groundwater were about $1600 \mu \mathrm{g} / \mathrm{L}$ 
at 4 to $5 \mathrm{~m} \mathrm{bgs,}$ with sum BTEX up to $13600 \mu \mathrm{g} / \mathrm{L}$. Tree-core samples (21) were taken and analyzed,

350 but among the BTEX compounds only xylene was found in a few samples (3 samples, with

351 maximum $0.3 \mu \mathrm{g} / \mathrm{kg}$ ) and the spatial correlation to BTEX compounds in groundwater was weak

352 (Algreen 2015). In the studies of Algreen (2015), toluene was the most frequently detected

353 compound (found in $59 \%$ of the samples), xylenes and ethylbenzene were measurable in $19 \%$ and

$35416 \%$ of the samples and benzene was measured in only $7 \%$ of all samples.

355 In the more successful applications of tree-core analysis, the levels of BTEX compounds

356 detected in tree-core samples, although reflecting the distribution in groundwater, were

357 comparatively low, corroborating with the findings of this study. At the Szprotawa former military

358 airport in Poland, concentrations of BTEX compounds of $>1400 \mu \mathrm{g} / \mathrm{L}$ (sum of BTEX

359 approximately 20:20:500:900 $\mu \mathrm{g} / \mathrm{L} \mathrm{B}: \mathrm{T}: \mathrm{E}: \mathrm{X}$, varying with sample) in groundwater (1.5 to $2.2 \mathrm{~m}$

360 depth) and of 100 to $240 \mathrm{mg} / \mathrm{kg}$ soil (dry weight sum of BTEX approximately 2:10:75:150 mg/kg

361 B:T:E:X, varying with sample) were determined around the abandoned fuel station (Algreen, 2015;

362 Algreen et al. 2015). Because of the absence of trees growing on the hot spot, cores of nearby trees

363 were sampled and contained a maximum of $27 \mu \mathrm{g} / \mathrm{kg}$ (sum of BTEX, recalculated from $\mu \mathrm{g} / \mathrm{L}$ for a

364 wood density of $1 \mathrm{~kg} / \mathrm{L} ; 4: 12: 5: 6 \mu \mathrm{g} / \mathrm{kg}$ B:T:E:X) (Algreen, 2015; Algreen et al. 2015).

365 Landmeyer et al. (2000) found MTBE, BTEX and trimethylbenzene in tree cores from trees

366 growing above a gasoline-contaminated shallow aquifer at a gasoline station near Beaufort, South

367 Carolina (USA). Concentrations of benzene ranged from below detection limit to $7.2 \mu \mathrm{g} / \mathrm{L}$ and were

$368508 \mu \mathrm{g} / \mathrm{L}$ in an adjacent groundwater well. Toluene had a better tree uptake, with the highest levels

369 of $26.2 \mu \mathrm{g} / \mathrm{L}$ and $674 \mu \mathrm{g} / \mathrm{L}$ in the tree core and groundwater, respectively. Similarly at a gas station

370 in Tel Aviv (Israel), Sorek et al. (2008) detected relatively low concentrations of the BTEX

371 compounds $(<100 \mu \mathrm{g} / \mathrm{kg})$ in tree cores from trees growing directly above a lens of petroleum

372 hydrocarbons floating on the groundwater table at $8 \mathrm{~m} \mathrm{bgs}$, whereas the concentrations in the nearby

373 groundwater well were higher: $1100 \mu \mathrm{g} / \mathrm{L}$ for benzene, $2400 \mu \mathrm{g} / \mathrm{L}$ toluene, and $860 \mu \mathrm{g} / \mathrm{L}$ for xylene. 
Holm (2011) reported the opposite outcome in tree-core samples taken at a former military base

375 in Potsdam-Krampnitz near Berlin, Germany. Benzene and other BTEX compounds were present in

376 most samples and in large amounts, but there was an insignificant correlation with groundwater

377 BTEX concentrations. It is likely that the core samples, measured by HS-SPME, were contaminated

378 by background benzene in the air or during handling or transportation.

379 All these study sites with non-detectable or low levels of BTEX compounds in tree-core

380 samples have in common a characteristic, which distinguishes them from the present study: either

381 they have a high depth to groundwater of $\geq 8 \mathrm{~m}$ bgs (Zeitz, Hradcany and Tel Aviv sites; Table 3) or

382 the aquifer is constrained by aquitards such as horizontal clay layers, which act as barriers to the

383 contact between tree roots and vapour phase of BTEX compounds or the capillary fringe (Zeitz,

384 Gentofte and Søllerød sites; Table 3). By contrast, successful detections of BTEX compounds have

385 been reported from contaminated sites with shallow groundwater at $2.5 \mathrm{~m}$ bgs or less (Szprotawa

386 and this study; Table 3). This leads to the conclusion that tree-core analysis can reliably detect

387 petroleum hydrocarbons such as BTEX compounds only at field sites with shallow unconfined

388 aquifers and permeable soils. Moreover, there is a risk of sample contamination because benzene or

389 toluene is widespread used.

390 5. Conclusions

391 The following conclusions are drawn from this research:

392 1. Tree-core sampling is restrained by the presence and distribution of mature trees and further by

393 the extensive marshes and stillwater bodies at the landfill site.

$3942 . \quad$ The detection of BTEX compounds in tree-core samples collected at the landfill site and local

395 control area indicates contamination of shallow groundwater $(\sim 2.5 \mathrm{~m}$ deep $)$ by waste disposal at

396 the landfill site, whereas the local control area is influenced by the migration of contaminant

397 off-landfill site. 
3. Uptake and accumulation of BTEX constituents vary between tree species: higher concentrations of toluene dominate in black spruce, whereas concentrations of benzene, ethylbenzene, $\mathrm{m}$ - and $\mathrm{p}$ xylenes, and o-xylene fall within similar range in all the examined tree

401 species.

4. An anomalous zone of high sum BTEX concentrations has been identified at the landfill site to guide the drilling of boreholes and wells for further investigations of the site.

5. While negative results for MTBE in tree-core samples were obtained, suggesting the absence of MTBE in groundwater, continued site monitoring is recommended.

6. A shallow unconfined aquifer and permeable soils are important field site characteristics for the successful application of tree-core analysis for petroleum hydrocarbons, such as BTEX compounds.

7. Tree-core analysis is potentially an excellent field-screening tool during preliminary site assessments for petroleum hydrocarbon-contaminated groundwater in remote subarctic regions. This method can provide first-hand data to assist solid waste management and pollution control authorities in minimizing or preventing possible environmental damages.

\section{Acknowledgements}

414 The authors are indebted to the Canadian Department of National Defence for its interest and 415 support and for access to the landfill site, and to the municipality of Happy Valley-Goose Bay for 416 supporting this research project. Special thanks to C. Cooney, environmental officer Canadian Force

417 Base 5 Wing Goose Bay, and D. AuCoin, M. Clough and other staff at the environmental office of 418 Defence Construction Canada Goose Bay for their generous logistical and field support, and for 419 access to unpublished contract reports on the landfill site assessment and remediation. R. Sparkes 420 (Labrador Institute) graciously assisted with community consultation at various stages of the project.

421 M. Mills, D. Frawley and S. Murphy (Labrador Institute) are acknowledged for their assistance 
422 during tree-core sampling. We thank G. Van Biesen (Memorial University) for his analytical

423 assistance. D. Frawley also kindly prepared the figures for this manuscript. M. Mills (Labrador

424 Institute) and D. Chipley (Queen's University) are thanked for their constructive editorial comments

425 that greatly improved this manuscript. We appreciate additional insightful comments by

426 Environmental Sciences and Pollution Research and four anonymous reviewers. This research

427 benefited from financial support by the Harris Centre MMSB Waste Management Applied Research

428 Fund 2014-2015 and the Memorial Undergraduate Career Experience Program (MUCEP) grant-

429 Spring 2014 to M. L.D. Fonkwe. This research is also supported by funding from the Atlantic

430 Canada Opportunities Agencies (ACOA) and the Department of Business, Tourism, Culture and

431 Rural Development, Newfoundland and Labrador (BTCRD NL).

\section{References}

Algreen M (2015) The feasibility of tree coring as a screening tool for selected contaminants in the

435 subsurface. PhD thesis at the Technical University of Denmark, Department of Environmental

436 Engineering. Available at: http://orbit.dtu.dk/en/publications/the-feasibility-of-tree-coring-as-a-

437 screening-tool-for-selected-contaminants-in-the-subsurface\%2880785fd4-7426-46b4-9b33-

$438 \quad 28883 \mathrm{e} 29 \mathrm{ad} 53 \% 29 . \mathrm{html}$. Accessed on 07 October 2015

439 Algreen M, Kalisz M, Stalder M, Martac E, Krupanek J, Trapp S, Bartke S (2015) Using pre-

440 screening methods for an effective and reliable site characterization at megasites. Environ Sci

$441 \quad$ Pollut Res 22(19):14673-14686

442 Allen A (2001) Containment landfills: The myth of sustainability. Journal of Engineering Geology

$443 \quad(60): 3-19$

444 AMEC Earth and Environmental (2009) TCE plume refinement - South escarpment area, CFB 5

445 Wing Goose Bay, Newfoundland and Labrador. Contract no: DCC\#HQ06010, Commission\#75 
446 AMEC Earth and Environmental (2011) Site investigation central/Eastern landfill, CFB 5 Wing

447 Goose Bay, Newfoundland and Labrador. Contract no: DCC\#IE090214, Commission \#2.3.5.1

448 Barrett A, Lawlor J (1995) The economics of waste management in Ireland. Economic and Social

$449 \quad$ Research Institute, Dublin

450 BFA Beatty Franz \& Associates Limited (1996) Remediation alternatives for South escarpment

451 drum removal risk assessment, Goose Bay. CFB 5 Wing Goose Bay, Newfoundland and

452 Labrador, contract reference\# 96-5

453 Borden RC, Daniel RA, LeBrun Iv LE, Davis CW (1997) Intrinsic biodegradation of MTBE and

454 BTEX in a gasoline-contaminated aquifer. Water Resour Res 33(5):1105-1115

455 Briggs GG, Bromilow RH, Evans AA (1982) Relationships between lipophilicity and root uptake

456 and translocation of non-ionised chemicals by barley. Pestic Sci 13:495-504

457 Burken JG, Schnoor, JL (1998) Predictive relationships for uptake of organic contaminants by

458 hybrid poplar trees. Environ Sci Technol 32:3379-3385

459 Burken JG, Vroblesky DA, Balouet JC (2011) Phytoforensics, dendrochemistry, and

460 phytoscreening: new green tools for delineating contaminants from past and present. Environ Sci

$461 \quad$ Technol 45(15):6218-6226

462 Christensen TH, Kjeldsen P, Bjerg PL, Jensen DL, Christensen JB, Baun A, Albrechtsen HJ, Heron

463 G (2001) Biogeochemistry of landfill leachate plumes. Appl Geochem 16:659-718

464 Cifrian E, Andres A, Viguri, RJ (2013) Estimating monitoring indicators and the carbon footprint of

465 municipal solid waste management in the region of Cantabria, Northern Spain. Waste Biomass

$466 \quad$ Valor 4:271-285

467 Curtis F, Lammey J (1998) Intrinsic remediation of a diesel fuel plume in Goose Bay, Labrador,

468 Canada. Environ Pollut 103: 203-210 
469 Cutter BE, Guyette RP (1993) Anatomical, chemical and ecological factors affecting tree species

$470 \quad$ choice in dendrochemistry studies. J Environ Quality 22:611-619

471 Dunn CE (2007) Biogeochemistry in mineral exploration. Hale, M. (ed.) Handbook of 367

472 exploration and environmental Geochemistry, Series 9, Elsevier, Amsterdam

473 Eggen T, Moeder M, Arukwe A (2010) Municipal landfill leachates: A significant source for new $474 \quad$ and emerging pollutants. Sci Total Environ 408(21):5147-5157

475 El-Fadel M, Findikakis A, Leckie J (1997) Environmental impacts of solid waste landfilling. J

476 Environ Manage 50 (1):1-25

477 El-Fadel M, Sadek S, Chahine W (2001) Environmental management of quarries as waste disposal $478 \quad$ facilities. J Environ Manage 4:515-531

479 FEI Franz Environmental Inc. (2006) Hydrogeological Study of the South Escarpment Area, CFB 5 480 Wing Goose Bay, Newfoundland and Labrador. Contract no: DND Report\#06-27

481 Fetta D, Papadopoulos A, Loizidou M (1999) A study on the landfill leachate and its impact on the 482 groundwater quality of the greater area. Environ Geochem Health 21(2):175-190

483

484

485

486

487

488

489

490

491

492
Heiden AC, Kobel K, Komenda M, Koppmann R, Shao M, Wildt J (1999) Toluene Emissions from Plants. Geophy Res Lett 26(9): 1283-1286

Holm O (2011) Development and application of a method for investigation and monitoring of CVOC contaminated sites by taking samples from plants. $\mathrm{PhD}$ thesis at the Technical University of Berlin, faculty III- Prozesswissenschaften (in German). Available at: https://opus4.kobv.de/opus4-tuberlin/frontdoor/index/index/docId/3182. Accessed on 13 October 2015

Holm O, Rotard W, Trapp S, Dési R (2011) Guide to Phytoscreening: Using tree core sampling and chemical analyses to investigate contamination in the groundwater and soil, Federal Ministry of Education and Research, Germany: 27. Available at: 
$494 \quad$ Accessed on 16 August 2013.

495

496

497

498

499

500

501

502

503

504

505

506

507

508

509

510

511

512

513

514

515

JWEL Jacques Whitford Environment Limited (1992) Environmental Clean-up study, CFB 5 Wing Goose Bay, Newfoundland and Labrador. Contract no: JWEL Project\#7250

Kjeldsen P, Barlaz MA, Rooker AP, Baun A, Ledin A, Christensen TH (2002) Present and longterm composition of MSW landfill leachate: A review. Crit Rev Env Sci Technol 32(4):297-336

Landmeyer JE, Vroblesky DA, Bradley PM (2000) MTBE and BTEX in trees above gasolinecontaminated groundwater. In: Wickramanayake, G.B., and others (eds) Case studies in the remediation of chlorinated and recalcitrant compounds. Proceedings of the 2 nd international conference on remediation of chlorinated and recalcitrant compounds, Monterey, California, May 22-25, 2000, pp 17-24

Laner D, Fellner J, Brunner PH (2011) Environmental compatibility of closed landfills - assessing future pollution hazards. Waste Manage Res 29(1):89-98

Larsen M, Burken JG, Macháčková J, Karlson UG, Trapp S (2008) Using tree core samples to monitor natural attenuation and plume distribution after a PCE spill. Environ. Sci. Technol. 42:1711-1717

Limmer MA, Balouet JC, Karg F, Vroblesky DA, Burken JG (2011) Phytoscreening for chlorinated solvents using rapid in vitro SPME sampling: Application to urban plume in Verl, Germany. Environ Sci Technol, 45(19):8276-8282

Limmer MA, Burken JG (2015) Phytoscreening with SPME: Variability Analysis. Int J Phytorem 17(11):1115-1122

Liverman DGE (1997) Quaternary Geology of the Goose Bay Area. Current Research, Department of Mines and Energy, Geological Survey, Newfoundland and Labrador, Report 97-1:173-182 
516 Ma X, Richter AR, Albers S, Burken JG (2004) Phytoremediation of MTBE with hybrid poplar

$517 \quad$ trees. Int J Phytoremediat 6(2):157-167

518 Machackova J, Wittlingerova Z, Vlk K, Zima J, Linka A (2008) Comparison of two methods for

519 assessment of in situ jet-fuel remediation efficiency. Water Air Soil Poll (187):181-194

520 Manfredi S, Tonini D, Christensen TH (2009) Landfilling of waste: accounting of greenhouse gases

521 and global warming contributions. Waste Manage Res 27(8):825-836

522 Newman LA, Gordon MP, Heilman P, Cannon DL, Lory E, Miller K, Osgood J, Strand SE (1999)

523 Phytoremediation of MTBE at a California naval site. Soil \& Groundwater Cleanup, Feb./March,

$524 \quad 1999: 42-45$

525 Nichols EG, Cook RL, Landmeyer JE, Atkinson B, Malone DR, Shaw G, Woods L (2014)

526 Phytoremediation of a petroleum-hydrocarbon contaminated shallow aquifer in Elizabeth City,

527 North Carolina, USA. Remed J 24:29-46

528 Nunn GAG, van Nosttrand T (1996) Geology of the Kenemich River map area (NTS 13G/SW),

529 Labrador. Department of Mines and Energy, Geological Survey, Newfoundland and Labrador,

$530 \quad$ Report 96-1:73-83

531 Padilla KL, Anderson KA (2002) Trace element concentration in tree-rings biomonitoring centuries

532 of environmental change. Chemosphere 49:575-585

533 Papastergios G, Fernandez-Turiel J-L, Filippidis A, Gimeno DA (2011) Determination of

534 geochemical background for environmental studies of soils via the use of HNO3 extraction and

535 Q-Q plots. Environ Earth Sci 64:743-751

536 Reimann C, Filzmoser P, Garrett RG (2005) Background and threshold: critical comparison of

537 methods of determination. Sci Total Environ 346:1-16. 
538 Rein A, Trapp S (2009) Model Driven Soil Probing, Site Assessment and Evaluation, EU FP 7

539 Project Grant Nr. 213161, Activity report 2009. Cited in Holm O, Rotard W, Trapp S, Dési R.

540 (2011): Guide to Phytoscreening - Using tree core sampling and chemical analyses to investigate

541 contamination in the groundwater and soil. Available at:

542 www.ufz.de/export/data/38/34096_Guide_to_Phytoscreening_20111121_FINAL.pdf. Accessed

$543 \quad$ on 11 August 2015

544 Rowe RK, Quigley RM, Booker JR (1997) Clayey barrier systems for waste disposal facilities.

$545 \quad$ Chapman and Hall

546 Ryan M (2010): Environmental standards for municipal solid waste landfill sites, Newfoundland and

547 Labrador. Government of Newfoundland and Labrador. Available at: http://www.env.gov.nl.ca/.

$548 \quad$ Accessed on 09 June 2015.

549 Sawhney LB, Kozloski RP (2004) Organic Pollutants in Leachates from Landfill Sites. J Environ

$550 \quad$ Qual $13(3): 349-352$

551 Schumacher JG, Struckhoff GC, Burken JG (2004) Assessment of subsurface chlorinated solvent

552 contamination using tree cores at the Front Street site and a former dry cleaning facility at the

553 Riverfront Superfund Site, NewHaven, Missouri, 1999-2003: U.S. Geological Survey Scientific

554 Investigations Report 2004-5049, 35 p. Available at: http://mo.water.usgs.gov/Reports/sir2004-

555 5049-schu/complete.pdf. Accessed on June 11, 2015.

556 Serco (2001) Remedial options evaluation, stillwater \#1. Canadian Department of National Defence, 557 Goose Bay, Labrador.

558 Slack RJ, Gronow JR, Voulvoulis N (2005) Household hazardous waste in municipal landfills:

$559 \quad$ contaminants in leachate. Sci Total Environ 337:119-137 
561 Tsechansky L, Weisbrod N, Graber ER (2008) "Phytoscreening": The use of trees for discovering

562 subsurface contamination by VOCs. Environ Sci Technol 42(2):536-542

563 Squillace PJ, Pankow JF, Korte NE, Zogorski JS (1997) Review of the environmental behavior and

564 fate of methyl tertiary-butyl ether. Environ Toxicol Chem 16:1836-1844

565 Trapp S (2007) Fruit tree model for uptake of organic compounds from soil and air. SAR - QSAR

$566 \quad$ Environ. Res. 18(3-4):367-387

567 Trapp S, Karlson U, Larsen M, Legind C (2005) Correlation between below and above surface

568 contamination. Biological procedures for diagnosing the status and predicting evolution of

569 polluted environments BIOTOOL project, deliverable 12.

570 Valvasori A, Fonkwe DLM, Piercey JS, Conliffe J (2015) Orthomagmatic Fe-Ti-V oxide

571 mineralization hosted in Paleoproterozoic anorthosite in the Cape Caribou River Allochthon,

572 Grenville Province, Southeast Labrador: Preliminary Results. Current Research, Department of

573 Natural Resources, Geological Survey of Newfoundland and Labrador, Report 15-1:125-138

574 Vroblesky DA (2008) User's guide to the collection and analysis of tree cores to assess the

575 distribution of subsurface volatile organic compounds: U.S. Geological Survey Scientific

576 Investigations Report 2008-5088. Available at: http://pubs.water.usgs.gov/sir2008-5088.

$577 \quad$ Accessed on 05 June 2013

578 Vroblesky DA, Clinton BD, Vose JM, Casey CC, Harvey GJ, Bradley PM (2004) Ground water

579 chlorinated ethenes in tree trunks: case studies, influence of recharge, and potential degradation

580 mechanism. Ground Water Monit R, 24(3):124-138

581 Vroblesky DA, Nietch CT, Morris JT (1999) Chlorinated ethenes from ground water in tree trunks.

$582 \quad$ Environ Sci Technol 33(3):510-515 
583 Wardle RJ, Ash, C (1986) Geology of the Goose Bay-Goose River area. Current Research, Mineral

584 Department of Mines and Energy, Geological Survey, Newfoundland and Labrador, Report 86-

$585 \quad 1: 113-123$

586 Weishaar JA, Tsao D, Burken J G (2009) Phytoremediation of BTEX hydrocarbons: Potential

587 impacts of diurnal groundwater fluctuation on microbial degradation. Int J Phytorem 11(5):509-

$588 \quad 523$

589 Wells C (2013) 5 Wing Goose Bay remediation project-A case study in sustainability? RPIC Federal

590 Contaminated Sited Regional Workshop, Halifax (Nova Scotia), June 19, 2013. Available at:

591 http://www.rpic ibic.ca/. Accessed on 08 October 2013

592 Wilson J, Bartz R, Limmer M, Burken J (2013) Plants as bio-indicators of subsurface conditions:

593 impact of groundwater level on BTEX Concentrations in trees. Int J Phytorem 15(3):257-267

594 White ML, Russo RS, Zhou Y, Ambrose JL, Haase K, Frinak EK, Sive BC (2009) Are biogenic

595 emissions a significant source of summertime atmospheric toluene in the rural Northeastern

$596 \quad$ United States? Atmos Chem Phys 9(1): 81-92

597 Wittlingerova Z, Machackova J, Petruzelkova A, Trapp S, Vlk K, Zima J (2013) One-year

598 measurements of chloroethenes in tree cores and groundwater at the SAP Mimoň Site, Northern

599 Bohemia.Environ Sci Pollut Res Int 20(2):834-847

600 Zagozewski R, Judd-Henrey I, Nilson S, Bharadwaj L (2011) Perspectives on Past and Present

601 Waste Disposal Practices: A Community-Based Participatory Research Project in Three

602 Saskatchewan First Nations Communities. Environmental Health Insights 5:9-20

603 
605 Fig. 1 Map (from Google Earth) showing the former landfill site and major dump areas along the 606 south boundary of Canadian Force Base 5 Wing Goose Bay; the area of tree-core sampling is

607 outlined. The local control site located outside the landfill site is indicated. An inset map of Canada 608 shows the location of the study area, the remote community of Happy Valley-Goose Bay and the 609 city of St. John's where the core samples were freighted for analysis.

610 Fig. 2 Map of the area of tree-core sampling showing the locations of sampled trees by species; the 611 numbers represent of the tree-core samples. Locations of major stillwaters, monitoring wells, and 612 contours of BTEX plumes in groundwater collected in summer 2005 and Sept.-Oct. 2006 (AMEC 613 2009; FEI 2006), in the vicinity of the sampling area are also shown. The direction of groundwater 614 flow is indicated.

615 Fig. 3 Normal quantile - quantile (Q-Q) plot showing the first bend of the slope curve at sum BTEX 616 concentration of $1.7 \mu \mathrm{g} / \mathrm{L}$, which separates the sum BTEX concentrations into two populations: (1)

617 background (lower) values, represented by grey squares; and (2) anomalous (higher) values, 618 represented by orange circles for core samples containing higher levels of toluene and yellow circles 619 for core samples containing higher levels of benzene.

620 Fig. 4 Spatial distribution maps of sum BTEX concentrations in tree-core samples for each tree 621 species: black spruce (top), trembling aspen (middle) and white birch (bottom). The numbers 622 represent the sampled trees. Also shown are the nearby stillwaters, monitoring wells and contours of 623 BTEX plumes in groundwater collected in summer 2005 and September-October 2006 (FEI 2006; 624 AMEC 2009). Note that the clustering of anomalous values of sum BTEX compounds in tree-core 625 samples is observed between stillwater \#2 and \#3 and at the vicinity of stillwater \#4. 
Table 1 Location, tree characteristics, and concentrations in micrograms per liter $(\mu \mathrm{g} / \mathrm{L})$ of the

627 petroleum hydrocarbon constituents benzene, toluene, ethylbenzene, m-and p-xylene, and o-xylene

628 in the headspace of vials containing tree cores collected at landfill site in Happy Valley-Goose Bay,

629 August-September 2014.

630 Notes: MTBE was not found in tree cores. Resulting values below the QLs of $0.4 \mu \mathrm{g} / \mathrm{L}$ for benzene, 631 toluene, ethylbenzene and o-xylene, and of $0.8 \mu \mathrm{g} / \mathrm{L}$ for $\mathrm{m}$ - and $\mathrm{p}-\mathrm{xylene}$ were set to half $\mathrm{QL}$ values $6320.2 \mu \mathrm{g} / \mathrm{L}$ and $0.8 \mu \mathrm{g} / \mathrm{L}$, respectively for representation. Dup = duplicate sample; a.s.l = above sea

633 level; $<\mathrm{DL}=$ below detection limit; "-" = co-elution, ratios of quantification and confirmatory ions

634 do not conform to those obtained from a standard.

635 Table 2 Location, tree characteristics and concentrations in micrograms per liter $(\mu \mathrm{g} / \mathrm{L})$ of the

636 petroleum hydrocarbon constituents benzene, toluene, ethylbenzene, m-and p-xylene, and o-xylene

637 in the headspace of vials containing tree cores collected at the local control site in Happy Valley-

638 Goose Bay, August-September 2014.

639 Notes: MTBE was not found in tree cores. Resulting values below the QLs of $0.4 \mu \mathrm{g} / \mathrm{L}$ for benzene, 640 toluene, ethylbenzene and o-xylene, and of $0.8 \mu \mathrm{g} / \mathrm{L}$ for $\mathrm{m}$ - and $\mathrm{p}$ - $\mathrm{xylene}$ were set to half QL values $6410.2 \mu \mathrm{g} / \mathrm{L}$ and $0.8 \mu \mathrm{g} / \mathrm{L}$, respectively for representation. Dup $=$ duplicate sample; a.s. $1=$ above sea 642 level; $<\mathrm{DL}=$ below detection limit; "-" = co-elution, ratios of quantification and confirmatory ions 643 do not conform to those obtained from a standard.

644 Table 3 Overview of field site characteristics and measurement methods of petroleum hydrocarbons 645 (especially BTEX compounds) in tree-core samples from reports found in open literature and the 646 present study.

647 Note: HS-GC-MS = headspace-gas chromatography-mass spectrometry; HS-SPME-GC-MS = 648 headspace solid-phase microextraction-gas chromatography-mass spectrometry; $\mathrm{GW}=$ groundwater. 


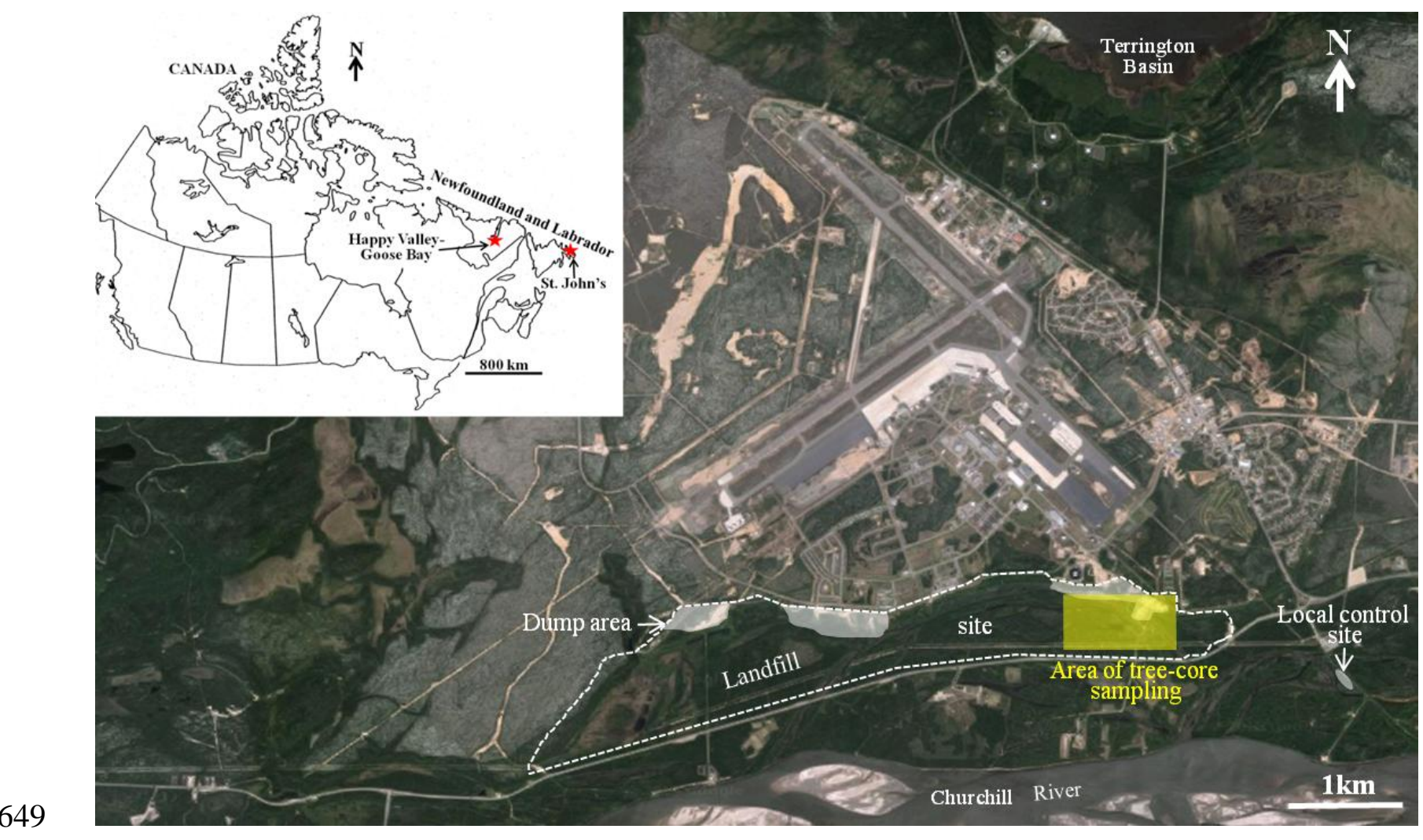

650 Fig. 1 Map (from Google Earth) showing the former landfill site and major dump areas along the

651 south boundary of Canadian Force Base 5 Wing Goose Bay; the area of tree-core sampling is

652 outlined. The local control site located outside the landfill site is indicated. An inset map of Canada

653 shows the location of the study area, the remote community of Happy Valley-Goose Bay and the

654 city of St. John's where tree-core samples were freighted for analysis. 


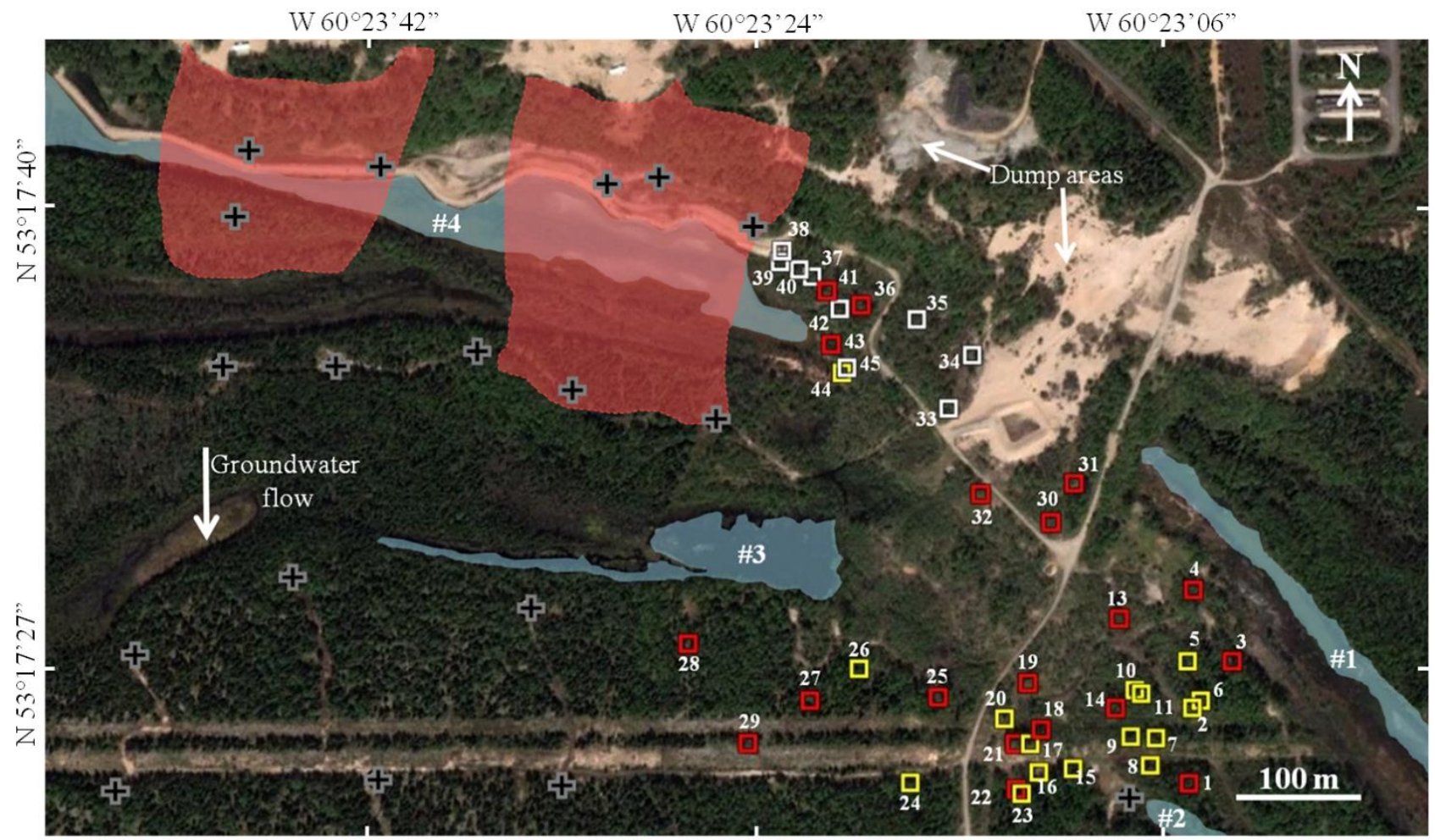

Base map from Google Earth

World Geodetic System Datum Projection

WGS84

Nest of monitoring wells

BTEX plume (FEI 2006; AMEC 2009)

Stillwater

回 Trembling aspen

回 Black spruce

回 White birch

657 Fig. 2 Map of the area of tree-core sampling showing the locations of sampled trees by species; the

658 numbers represent of the tree-core samples. Locations of major stillwaters, monitoring wells, and

659 contours of BTEX plumes in groundwater collected in summer 2005 and Sept.-Oct. 2006 (AMEC

660 2009; FEI 2006), in the vicinity of the sampling area are also shown. The direction of groundwater

661 flow is indicated. 


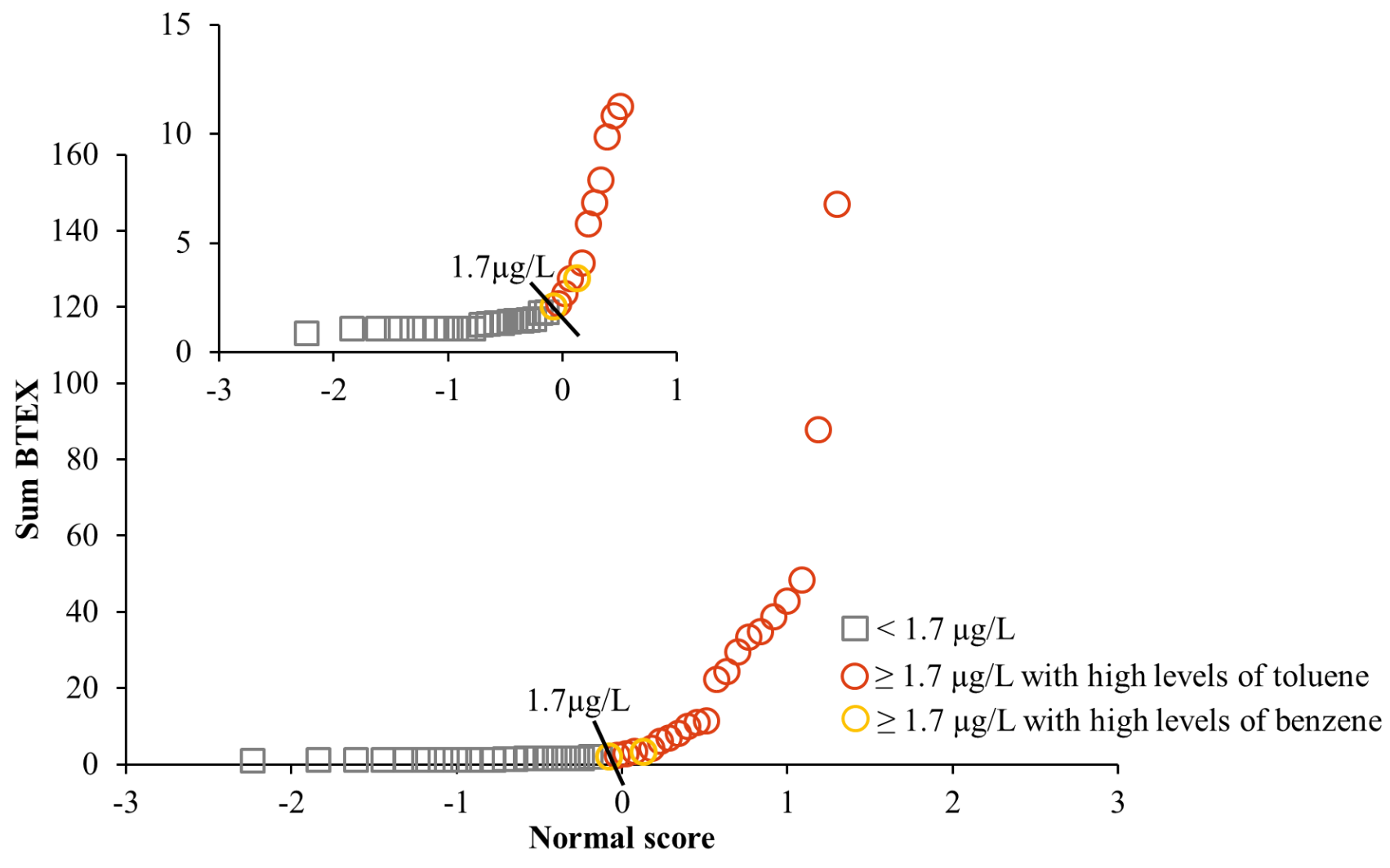

664 Fig. 3 Normal quantile - quantile (Q-Q) plot showing the first bend of the slope curve at sum BTEX

665 concentration of $1.7 \mu \mathrm{g} / \mathrm{L}$, which separates the sum BTEX concentrations into two populations: (1)

666 background (lower) values, represented by grey squares; and (2) anomalous (higher) values,

667 represented by orange circles for core samples containing higher levels of toluene and yellow circles

668 for core samples containing higher levels of benzene. 

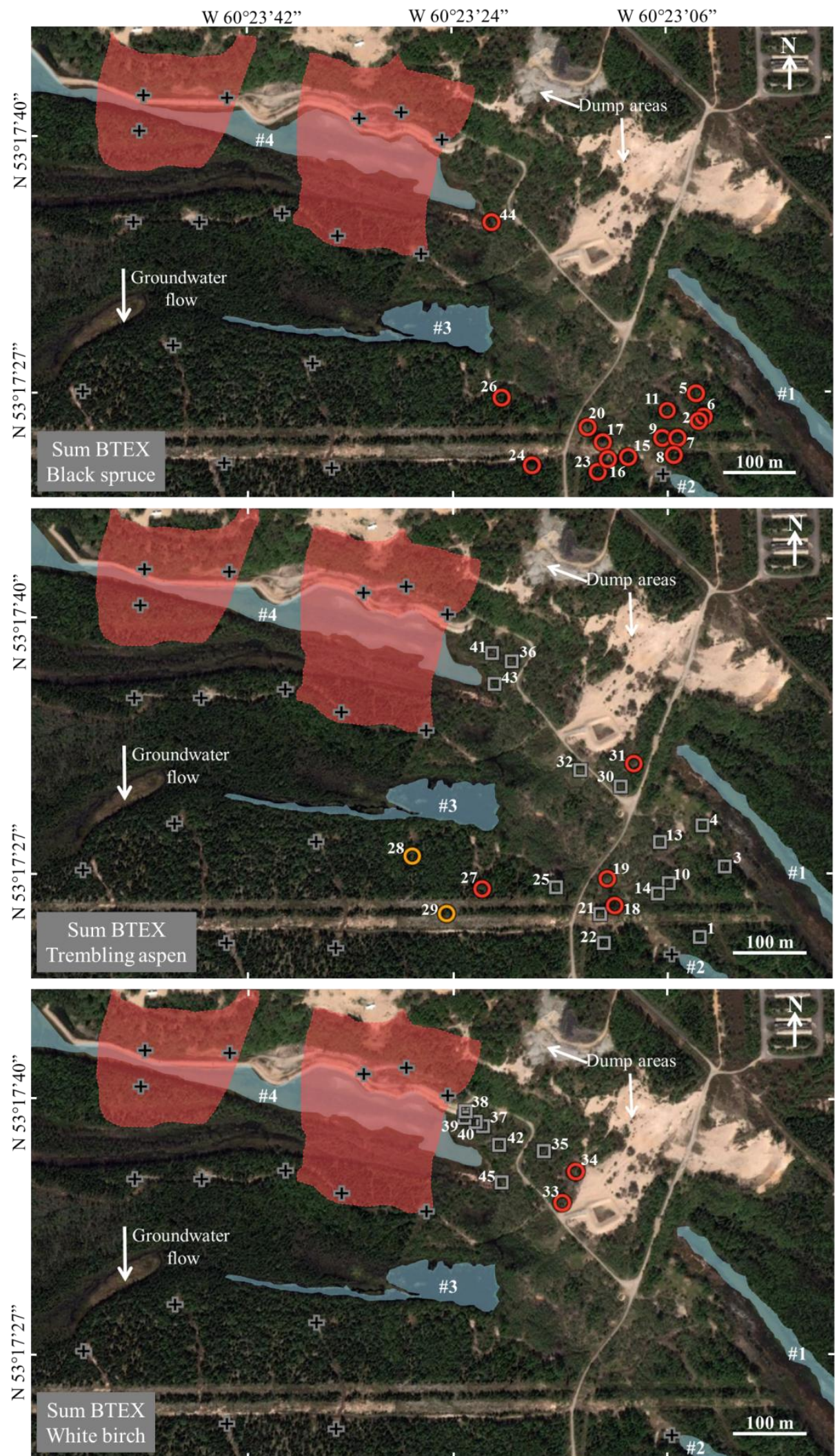

Base map from Google Earth

World Geodetic System Datum Projection

WGS84

EXPLANATION

回 $<1.7 \mu \mathrm{g} / \mathrm{L}$

] $\geq 1.7 \mu \mathrm{g} / \mathrm{L}$ with high levels of toluene

- $\geq 1.7 \mu \mathrm{g} / \mathrm{L}$ with high levels of benzene 
671 Fig. 4 Spatial distribution maps of sum BTEX concentrations in tree-core samples for each tree 672 species: black spruce (top), trembling aspen (middle) and white birch (bottom). The numbers

673 represent the sampled trees. Also shown are the nearby stillwaters, monitoring wells and contours of 674 BTEX plumes in groundwater collected in summer 2005 and September-October 2006 (FEI 2006;

675 AMEC 2009). Note that the clustering of anomalous values of sum BTEX compounds in tree-core 676 samples is observed between stillwater \#2 and \#3 and at the vicinity of stillwater \#4. 
Table 1 Location, tree characteristics, and tree-cores concentrations in micrograms per liter $(\mu \mathrm{g} / \mathrm{L})$ of the petroleum hydrocarbon constituents benzene, toluene, ethylbenzene, m-and p-xylene, and o-xylene in the headspace of vials containing tree cores collected at landfill site in Happy Valley-Goose Bay, August-September 2014.

Notes: MTBE was not found in tree cores. Resulting values below the QLs of $0.4 \mu \mathrm{g} / \mathrm{L}$ for benzene, toluene, ethylbenzene and o-xylene, and of $0.8 \mu \mathrm{g} / \mathrm{L}$ for $\mathrm{m}$ - and p- xylene were set to half QL values $0.2 \mu \mathrm{g} / \mathrm{L}$ and $0.8 \mu \mathrm{g} / \mathrm{L}$, respectively for representation. Dup = duplicate sample; a.s.l = above sea level;

\begin{tabular}{|c|c|c|c|c|c|c|c|c|c|c|c|}
\hline 2 & $53^{\circ} 17^{\prime} 25.70^{\prime \prime}$ & $60^{\circ} 23^{\prime} 03.70^{\prime \prime}$ & 9 & Black spruce & 31 & 0.20 & 7.4 & 0.20 & - & - & 7.8 \\
\hline 3 & $53^{\circ} 17^{\prime} 27.00^{\prime \prime}$ & $60^{\circ} 23^{\prime} 01.80^{\prime \prime}$ & 10 & Trembling aspen & 39 & 0.20 & 0.63 & 0.20 & 0.40 & - & 1.4 \\
\hline 6 & $53^{\circ} 17^{\prime} 25.90^{\prime \prime}$ & $60^{\circ} 23^{\prime} 03.30^{\prime \prime}$ & 11 & Black spruce & 26 & 0.20 & 29.0 & 0.20 & - & - & 29.4 \\
\hline 7 & $53^{\circ} 17^{\prime} 24.90^{\prime \prime}$ & $60^{\circ} 23^{\prime} 05.40^{\prime \prime}$ & 11 & Black spruce & 21 & 0.20 & 10.8 & 0.20 & - & - & 11.2 \\
\hline 8 & $53^{\circ} 17^{\prime} 24.10^{\prime \prime}$ & $60^{\circ} 23^{\prime} 05.70^{\prime \prime}$ & 11 & Black spruce & 25 & 0.20 & 10.4 & 0.20 & - & - & 10.8 \\
\hline 9 & $53^{\circ} 17^{\prime} 24.90^{\prime \prime}$ & $60^{\circ} 23^{\prime} 06.60^{\prime \prime}$ & 11 & Black spruce & 19 & 0.20 & 5.4 & 0.20 & - & - & 5.8 \\
\hline 10 & $53^{\circ} 17^{\prime} 26.20^{\prime \prime}$ & $60^{\circ} 23^{\prime} 06.40^{\prime \prime}$ & 10 & Trembling aspen & 28 & 0.20 & 0.20 & 0.20 & 0.40 & - & 1.0 \\
\hline 14 & $53^{\circ} 17^{\prime} 25.70^{\prime \prime}$ & $60^{\circ} 23^{\prime} 07.30^{\prime \prime}$ & 11 & Trembling aspen & 24 & 0.20 & 0.47 & 0.20 & 0.40 & - & 1.3 \\
\hline 15 & $53^{\circ} 17^{\prime} 24.00^{\prime \prime}$ & $60^{\circ} 23^{\prime} 09.30^{\prime \prime}$ & 9 & Black spruce & 18 & 0.20 & 21.8 & 0.20 & - & - & 22.2 \\
\hline 16 & $53^{\circ} 17^{\prime} 23.90^{\prime \prime}$ & $60^{\circ} 23^{\prime} 10.90^{\prime \prime}$ & 11 & Black spruce & 18 & 0.20 & 23.7 & 0.20 & - & - & 24.1 \\
\hline 17 & $53^{\circ} 17^{\prime} 24.70^{\prime \prime}$ & $60^{\circ} 23^{\prime} 11.30^{\prime \prime}$ & 10 & Black spruce & 18 & 0.20 & 32.8 & 0.20 & - & - & 33.2 \\
\hline 18 & $53^{\circ} 17^{\prime} 25.10^{\prime \prime}$ & $60^{\circ} 23^{\prime} 10.80^{\prime \prime}$ & 1 & Trembling aspen & 30 & 0.20 & 1.4 & 0.20 & 0.40 & - & 2.2 \\
\hline 19 & $53^{\circ} 17^{\prime} 26.40^{\prime \prime}$ & $60^{\circ} 23^{\prime} 11.40^{\prime \prime}$ & 5 & Trembling aspen & 18 & 0.20 & 2.5 & 0.20 & 1.13 & - & 4.0 \\
\hline 20 & $53^{\circ} 17^{\prime} 25.40^{\prime \prime}$ & $60^{\circ} 23^{\prime} 12.50^{\prime \prime}$ & 4 & Black spruce & 33 & 0.20 & 6.4 & 0.20 & - & - & 6.8 \\
\hline 21 & $53^{\circ} 17^{\prime} 24.70^{\prime \prime}$ & $60^{\circ} 23^{\prime} 12.00^{\prime \prime}$ & 6 & Trembling aspen & 25 & 0.20 & 0.20 & 0.20 & 0.40 & - & 1.0 \\
\hline 22 & $53^{\circ} 17^{\prime} 23.30^{\prime \prime}$ & $60^{\circ} 23^{\prime} 11.70^{\prime \prime}$ & 6 & Trembling aspen & 23 & 0.20 & 0.20 & 0.20 & 0.40 & - & 1.0 \\
\hline
\end{tabular}




\begin{tabular}{|c|c|c|c|c|c|c|c|c|c|c|c|}
\hline \multirow{2}{*}{$\begin{array}{l}\text { Tree Identifier } \\
\text { (Fig. } 2 \text { and 3) }\end{array}$} & \multirow[b]{2}{*}{ Latitude } & \multirow[b]{2}{*}{ Longitude } & \multirow{2}{*}{$\begin{array}{c}\text { Elevation of } \\
\text { tree location } \\
\text { a.s.l. (m) }\end{array}$} & \multirow[b]{2}{*}{ Tree species } & \multirow{2}{*}{$\begin{array}{c}\text { Tree } \\
\text { diameter } \\
(\mathrm{cm})\end{array}$} & \multicolumn{5}{|c|}{ Concentrations $(\mu \mathrm{g} / \mathrm{L})$} & \multirow{2}{*}{$\begin{array}{c}\text { Sum } \\
\text { BTEX }\end{array}$} \\
\hline & & & & & & Benzene & Toluene & $\begin{array}{c}\text { Ethyl- } \\
\text { benzene }\end{array}$ & $\begin{array}{l}\text { m- and p- } \\
\text { xylene }\end{array}$ & o-xylene & \\
\hline 23 & $53^{\circ} 17^{\prime} 23.30^{\prime \prime}$ & $60^{\circ} 23^{\prime} 11.70^{\prime \prime}$ & 6 & Black spruce & 31 & 0.20 & 47.7 & 0.20 & - & - & 48.1 \\
\hline 24 & $53^{\circ} 17^{\prime} 23.60^{\prime \prime}$ & $60^{\circ} 23^{\prime} 16.90^{\prime \prime}$ & 6 & Black spruce & 27 & 0.20 & 34.2 & 0.20 & - & - & 34.6 \\
\hline 25 & $53^{\circ} 17^{\prime} 26.00^{\prime \prime}$ & $60^{\circ} 23^{\prime} 15.60^{\prime \prime}$ & 5 & Trembling aspen & 29 & 0.20 & 0.20 & 0.20 & 0.40 & - & 1.0 \\
\hline 25Dup & $53^{\circ} 17^{\prime} 26.00^{\prime \prime}$ & $60^{\circ} 23^{\prime} 15.60^{\prime \prime}$ & 5 & Trembling aspen & 29 & 0.20 & 0.80 & 0.20 & 0.40 & - & 1.6 \\
\hline 27 & $53^{\circ} 17^{\prime} 25.90^{\prime \prime}$ & $60^{\circ} 23^{\prime} 21.60^{\prime \prime}$ & 6 & Trembling aspen & 26 & 0.20 & 9.0 & 0.20 & 0.40 & - & 9.8 \\
\hline 28 & $53^{\circ} 17^{\prime} 27.50^{\prime \prime}$ & $60^{\circ} 23^{\prime} 27.30^{\prime \prime}$ & 8 & Trembling aspen & 25 & 1.1 & 0.43 & 0.20 & 0.40 & - & 2.1 \\
\hline 29 & $53^{\circ} 17^{\prime} 24.70^{\prime \prime}$ & $60^{\circ} 23^{\prime} 24.50^{\prime \prime}$ & 7 & Trembling aspen & 23 & 1.5 & 0.59 & 0.93 & 0.40 & - & 3.4 \\
\hline 30 & $53^{\circ} 17^{\prime} 30.90^{\prime \prime}$ & $60^{\circ} 23^{\prime} 10.30^{\prime \prime}$ & 14 & Trembling aspen & 24 & 0.20 & 0.60 & 0.20 & 0.40 & - & 1.4 \\
\hline 31 & $53^{\circ} 17^{\prime} 32.00^{\prime \prime}$ & $60^{\circ} 23^{\prime} 09.20^{\prime \prime}$ & 15 & Trembling aspen & 18 & 0.20 & 0.94 & 0.20 & 0.40 & - & 1.7 \\
\hline 35 & $53^{\circ} 17^{\prime} 36.60^{\prime \prime}$ & $60^{\circ} 23^{\prime} 16.60^{\prime \prime}$ & 13 & White birch & 32 & 0.20 & 0.40 & 0.20 & 0.40 & 0.20 & 1.2 \\
\hline 35Dup & $53^{\circ} 17^{\prime} 36.60^{\prime \prime}$ & $60^{\circ} 23^{\prime} 16.60^{\prime \prime}$ & 13 & White birch & 32 & 0.20 & 0.44 & 0.20 & 0.40 & 0.20 & 1.2 \\
\hline 36 & $53^{\circ} 17^{\prime} 37.00^{\prime \prime}$ & $60^{\circ} 23^{\prime} 19.20^{\prime \prime}$ & 10 & Trembling aspen & 25 & 0.20 & 0.53 & 0.20 & 0.40 & - & 1.3 \\
\hline 37 & $53^{\circ} 17^{\prime} 37.80^{\prime \prime}$ & $60^{\circ} 23^{\prime} 21.50^{\prime \prime}$ & 8 & White birch & 34 & 0.20 & 2.5 & 0.20 & 0.40 & 0.20 & 3.3 \\
\hline 38 & $53^{\circ} 17^{\prime} 38.50^{\prime \prime}$ & $60^{\circ} 23^{\prime 22.90 "}$ & 9 & White birch & 26 & $<\mathrm{DL}$ & 0.20 & 0.20 & 0.40 & 0.20 & 0.80 \\
\hline 39 & $53^{\circ} 17^{\prime} 38.20^{\prime \prime}$ & $60^{\circ} 23^{\prime 23.00 "}$ & 7 & White birch & 28 & 0.20 & 0.20 & 0.20 & 0.40 & 0.20 & 1.0 \\
\hline 40 & $53^{\circ} 17^{\prime} 38.00^{\prime \prime}$ & $60^{\circ} 23^{\prime} 22.10^{\prime \prime}$ & 6 & White birch & 25 & 0.20 & 0.20 & 0.20 & 0.40 & 0.20 & 1.0 \\
\hline 41 & $53^{\circ} 17^{\prime} 37.40^{\prime \prime}$ & $60^{\circ} 23^{\prime} 20.80^{\prime \prime}$ & 6 & Trembling aspen & 30 & 0.20 & 0.20 & 0.20 & 0.40 & - & 1.0 \\
\hline 42 & $53^{\circ} 17^{\prime} 36.90^{\prime \prime}$ & $60^{\circ} 23^{\prime} 20.20^{\prime \prime}$ & 8 & White birch & 26 & 0.20 & 0.58 & 0.20 & 0.40 & 0.20 & 1.4 \\
\hline 43 & $53^{\circ} 17^{\prime} 35.90^{\prime \prime}$ & $60^{\circ} 23^{\prime} 20.60^{\prime \prime}$ & 8 & Trembling aspen & 34 & 0.20 & 0.20 & 0.20 & 0.40 & - & 1.0 \\
\hline
\end{tabular}


Table 2 Location, tree characteristics and tree-core concentrations in micrograms per liter $(\mu \mathrm{g} / \mathrm{L})$ of the petroleum hydrocarbon constituents benzene, toluene, ethylbenzene, $\mathrm{m}$-and $\mathrm{p}$-xylene, and o-xylene in the headspace of vials containing tree cores collected at the local control site in Happy Valley-Goose Bay, August-September 2014.

Notes: MTBE was not found in tree cores. Resulting values below the QLs of $0.4 \mu \mathrm{g} / \mathrm{L}$ for benzene, toluene, ethylbenzene and o-xylene, and of $0.8 \mu \mathrm{g} / \mathrm{L}$ for $\mathrm{m}$ - and p- xylene were set to half QL values $0.2 \mu \mathrm{g} / \mathrm{L}$ and $0.8 \mu \mathrm{g} / \mathrm{L}$, respectively for representation. Dup = duplicate sample; a.s.l = above sea level; $<\mathrm{DL}=$ below detection limit; "_" = co-elution, ratios of quantification and confirmatory ions do not conform to those obtained from a standard.

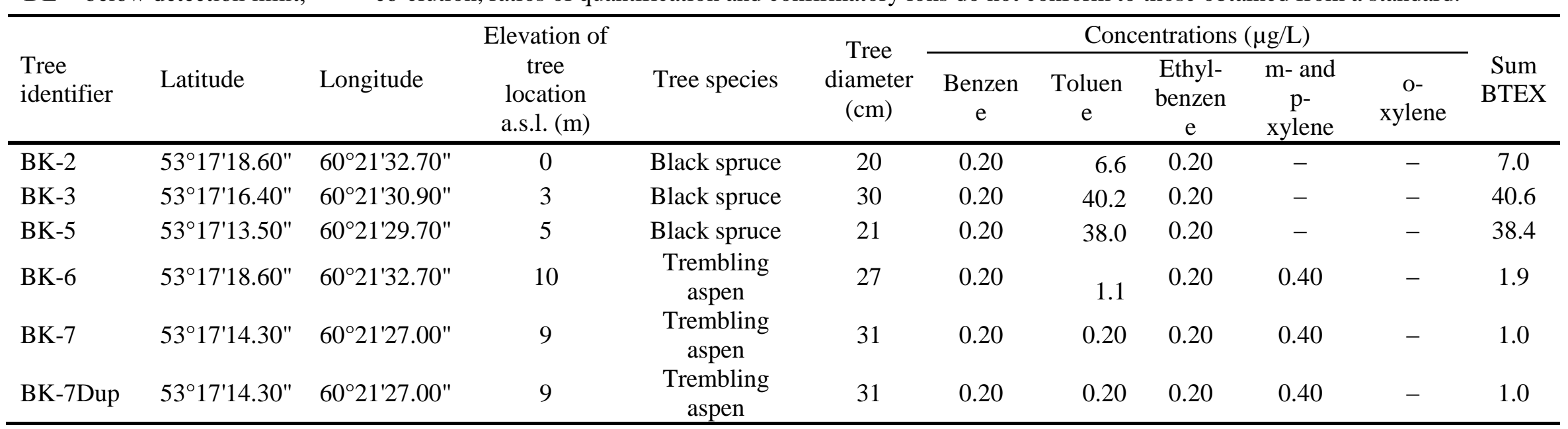


Table 3 Overview of field site characteristics and measurement methods of petroleum hydrocarbons (especially BTEX compounds) in treecore samples from reports found in open literature and the present study.

696 Note: HS-GC-MS = headspace-gas chromatography-mass spectrometry; HS-SPME-GC-MS = headspace solid-phase microextraction-gas

697 chromatography-mass spectrometry; GW = groundwater.

\begin{tabular}{|c|c|c|c|c|c|c|c|}
\hline Study area & Regional climate & $\begin{array}{l}\text { Depth to } \\
\text { groundwater } \\
\text { table (m) }\end{array}$ & $\begin{array}{l}\text { Groundwater } \\
\text { aquifer }\end{array}$ & $\begin{array}{l}\text { Compounds } \\
\text { measurement } \\
\text { method }\end{array}$ & Tree species & $\begin{array}{l}\text { Was tree-core } \\
\text { analysis } \\
\text { successful? }\end{array}$ & Sources \\
\hline $\begin{array}{l}\text { Gasoline station near } \\
\text { Beaufort, South } \\
\text { Carolina, USA }\end{array}$ & Humid subtropical & $0.6-3.9$ & Well-sorted sand & HS-GC-MS & Oak & yes & $\begin{array}{c}\text { Landmeyer et al. } \\
2000\end{array}$ \\
\hline $\begin{array}{l}\text { Hradčany site, former } \\
\text { Soviet military airport, } \\
\text { Czech Republic }\end{array}$ & $\begin{array}{l}\text { Continental, warm } \\
\text { dry summers }\end{array}$ & 8 & $\begin{array}{c}\text { Sand and gravel }(0 \\
-3 \mathrm{~m}) \text {, fine grained } \\
\text { sandstone }\end{array}$ & HS-GC-MS & $\begin{array}{l}\text { Conifers (spruce } \\
\text { and pine), birch }\end{array}$ & no & Trapp et al. 2005 \\
\hline $\begin{array}{l}\text { Former military base } \\
\text { Potsdam-Krampnitz } \\
\text { near Berlin, Germany }\end{array}$ & $\begin{array}{l}\text { Atlantic to } \\
\text { continental }\end{array}$ & $\begin{array}{c}1.3-7, \text { and } \\
>9\end{array}$ & $\begin{array}{l}\text { Fine to medium } \\
\text { sized sands } \\
\text { intermixed with } \\
\text { silt layers }\end{array}$ & $\begin{array}{l}\text { HS-SPME- } \\
\text { GC-MS }\end{array}$ & $\begin{array}{l}\text { Birch, willow, } \\
\text { poplar, locust, } \\
\text { maple, linden }\end{array}$ & $\begin{array}{l}\text { no (due to cross } \\
\text { contamination) }\end{array}$ & Holm 2011 \\
\hline Gentofte site, Denmark & $\begin{array}{l}\text { Humid continental } \\
\text { with mild summer }\end{array}$ & 5 & Silt, clay and sand & HS-GC-MS & Willow, poplar & $\begin{array}{c}\text { no (no correlation } \\
\text { to } \mathrm{GW} \text { ) }\end{array}$ & Algreen 2015 \\
\hline $\begin{array}{l}\text { Szprotawa former } \\
\text { military airport, Poland }\end{array}$ & $\begin{array}{l}\text { Continental, warm } \\
\text { dry summers }\end{array}$ & $\begin{array}{c}1.5-2.2 \\
(0.9 \text { to } 3.5)\end{array}$ & $\begin{array}{l}\text { Thin layer of silt } \\
\text { underlain with } \\
\text { sand and gravel }\end{array}$ & HS-GC-MS & $\begin{array}{l}\text { mostly willow } \\
\text { and poplar }\end{array}$ & yes & Algreen et al. 2015 \\
\hline $\begin{array}{l}\text { Former landfill site at } \\
\text { the Canada Force Base } \\
5 \text { Wing Goose Bay in } \\
\text { Happy Valley-Goose } \\
\text { Bay, Labrador, Canada }\end{array}$ & $\begin{array}{l}\text { Subarctic with } \\
\text { cool summer }\end{array}$ & $0-2.5$ & $\begin{array}{c}\text { Loose fine to } \\
\text { medium-grained } \\
\text { sands with scare } \\
\text { interbedded clayey } \\
\text { silt }\end{array}$ & HS-GC-MS & $\begin{array}{l}\text { Black spruce, } \\
\text { trembling aspen, } \\
\text { white birch }\end{array}$ & yes & This study \\
\hline
\end{tabular}

